Agropedology 2016, 26 (02), 149-164

\title{
Soil Mapping at Village Level in a Part of Amethi District, U.P. using IRS LISS-IV and Cartosat-1 Merged Data for Sustainable Land and Crop Management
}

\author{
P.P.S. Yadav*, Arjun Singh, G. Rajput and K. Singh \\ Agriculture Resource Division, Remote Sensing Application Centre-UP, Sec-G, Jankipuram, \\ Lucknow - 226021, India
}

\begin{abstract}
The study presents a soil survey carried out in two nyayapanchayats, consisting of 23 villages of Amethi district of Uttar Pradesh. The soil resource database has been generated by interpreting Resourcesat-1 LISS-IV and Cartosat-1 merged data on 1:10,000 scale. Six physiographic units have been delineated in the area and soil compositions in each unit have been correlated. Twelve soil series have been mapped. The soil database was integrated with plot (khasra) boundary which help in generating soil information at plot identified and level. Village level action plan for sustainable land and crop management has also been prepared. Information on land capability, land irrigability, crop suitability and Storie index rating have also been generated. It is observed that LISS-IV and Cartosat-1 merged satellite data help in generating village level soil information, useful for detailed micro-level planning. The soil problems identified in the area include sodicity, erosion, and poor drainage.
\end{abstract}

Keywords:, Geographic information system (GIS), high resolution satellite data, remote sensing landform - soil relationship

\section{Introduction}

Soil maps presently available in India are generally on 1:50,000 scale, which provide information that are regional in nature, rather than local and site-specific. With the focus of rural development planning having been shifted to village panchayats, it has become imperative that the soil resource information is prepared on a larger scale, with finer level of details so that these can be used for developmental planning at village level (Ravisankar and Thamappa 2004; Rao et al. 2004). Large scale soil mapping in India has been mostly done by traditional methods, using cadastral map (village map) as base (Jagdish Prasad et al. 2009; Anil Kumar et al. 2010; Sah et al. 2010 and Sankar et al. 2010). The scale of these maps varies from 1:4,000 to 1:10,000. However, mapping using village cadaster as base and soil sampling at fixed grid interval requires large number of observations and are time consuming and expensive (Simon 2010). Due to

*Corresponding Author Email: ppsyadav77@gmail.com these reasons, the use of satellite remote sensing data as a base for soil mapping has become common in recent years. The dynamic relationship between physiography and soils is utilized in deriving information on soils from satellite data (Singh and Dwivedi 1986;). Dwivedi (2001) has observed that proper identification of land type, drainage pattern and drainage condition, vegetation, land use, slope and relief is essential in the interpretation of satellite image for soil mapping. The use of satellite image has been reported to save about $60-80 \%$ time in soil mapping, as compared to manual methods (Liengsakul et al. 1993). With the availability of high resolution satellite data from new IRS satellite sensors like- IRS LISS-IV (5.8 m multispectral), IRS 1D PAN (5.8 m panchromatic), Cartosat-1 PAN (2.5m panchromatic), Cartosat- 2A PAN (1m panchromatic), their use for large scale soil mapping from 1:5000 to 1:12500 scale is becoming common in India (Dwivedi et al. 2001; Srivastava and Saxena 2004; Ardak et al. 2010; Wadodkar and Ravisankar 2011; Sahu et al. 2014). Kunwar et al (2010) have used 
IKONOS data with $1 \mathrm{~m}$ panchromatic and $4 \mathrm{~m}$ multispectral resolution in mapping of natural resources, including soils, on 1:4,000 scale for suggesting alternate land use in a hilly micro-watershed. High resolution LISS IV and Cartosat PAN data have also been used in soil mapping at village level in granitic terrain of Andhra Pradesh (Wadodkar and Ravisankar 2011), and in basaltic terrain of Central India (Sahu et al. 2016).Realizing the utility of satellite data in soil resource mapping, a study was taken up in two nyaya panchayats covering 23 villages of Amethi district of Uttar Pradesh, using IRS LISS-IV and Cartosat-1PAN data, to prepare soil map on 1:10,000 scale that would facilitate natural resource developmental planning at the village level.

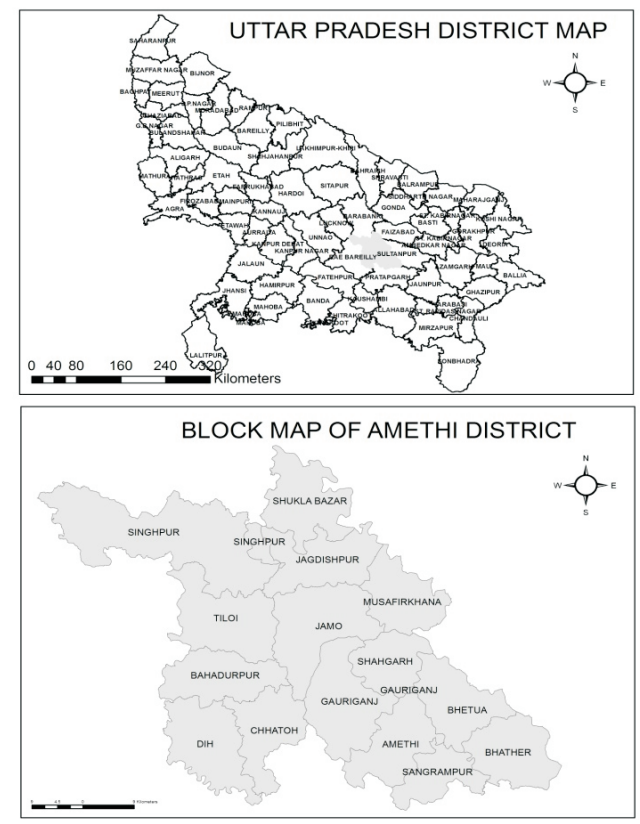

Fig. 1 Location Map of Tala and Korari Girdhar Shah Nayapanchayat, Distric Amethi, U.P

The climate of Amethi district is semi-arid subtropical monsoon type. The cold days start from 15 November and last up to 15 March. However, severe cold days are in December and January. Hot summer months are May and June. Monsoon sets generally by the end of June and lasts up to the first week of October. The average annual rainfall of the past 6 years (2010-2015) is $775 \mathrm{~mm}$, about $80 \%$ of which is received between June and September. Mean maximum temperatures of $41.1 \mathrm{C}$ and $38.9 \mathrm{C}$ are recorded in the months of May and June, which are the hottest months. The month of April is also quite hot with a mean temperature

\section{Materials and Methods \\ Characteristics of the study area}

Amethi district came into existence in July 2010 by merging three tehsils of the erstwhile Sultanpur district and two tehsils of the erstwhile Raebareli district of Uttar Pradesh. The study area of two nyayapanchayats, i.e. Tala and Korari Girdhar Shah, of Amethi district lies between parallels of $81^{\circ} 44^{\prime} 55.186^{\prime \prime} \mathrm{E} / 26^{\circ} 11^{\prime} 23.152^{\prime \prime} \mathrm{N}$ latitude to $81^{\circ} 47^{\prime} 3.109 " \mathrm{E} / 26^{\circ} 6^{\prime} 37.629^{\prime \prime N}$ longitude (Fig.1). A total of 23 villages are included in these two nyaya panchayats, falling in block and district Amethi. Geographical area of these villages is $3567 \mathrm{ha}$. The distance of the study area from the district headquarter Amethi is $6 \mathrm{~km}$.

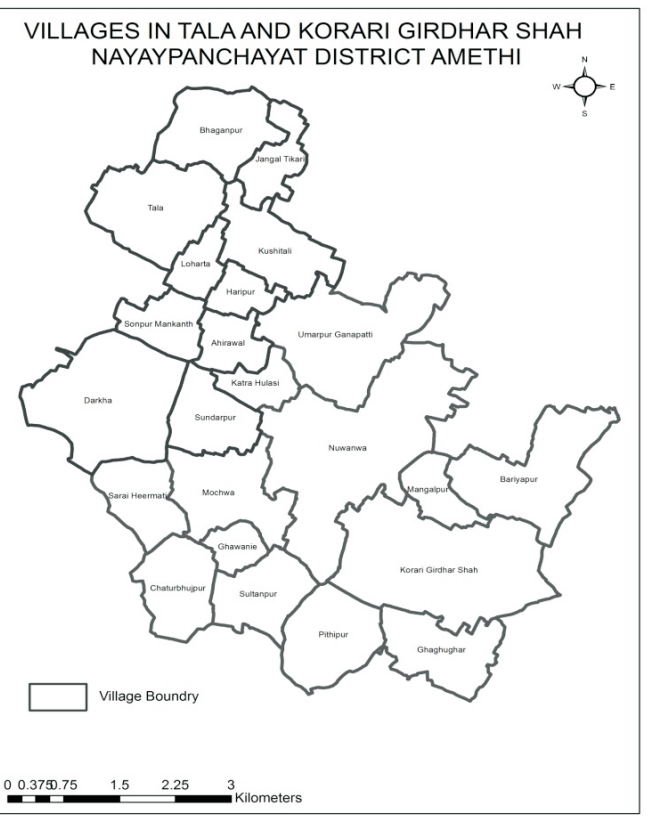

of $38.1 \mathrm{C}$. The mean minimum temperatures in the month of December and January are 7.7 C and 7.9C, respectively. The soil temperature regime of the study area is Hyperthermic and the soil moisture regime is Ustic (Anonymous, 1988). Block Amethi is a part of Lower Gangetic Plains. River Ganga has transported alluvial sediments especially from the Outer Himalayas and the Shivaliks. During the process of deposition of alluvium, water courses have been changed gradually. The present ox-bows and the buried channels at places are examples of the changes in water courses. The general slope is from north-west to south-east. The central 
part is slightly elevated, on which the Amethi distributary of Sharda Sahayak canal is located. The land is very gently sloping out from the distributary towards the north-east and the south-west.The land use/land cover in the study area comprises mainly of agricultural land, fallow land, plantation, waterbody and sodic wastelands. About $68 \%$ of the area is covered by seasonal crops and about $15 \%$ by orchards and plantations.

\section{Dataused}

Digital data of Indian Remote Sensing Satellite (IRS) P6 LISS-IV with $5.8 \mathrm{~m}$ resolution and Cartosat-1 with $2.5 \mathrm{~m}$ resolution of April 2011 were used. Ancillary data referred include Survey of India topographical maps 63F/12 and 63F/16 (1:50,000 scale). Cadastral maps of all the 23 villages falling within the two nyaya panchayats were taken from the district office, Amethi.

\section{Methodology}

A detailed soil mapping of Tala and Korari Girdhar Shah nyayapanchayats was carried out using IRS LISS-IV and Cartosat-1 PAN data. Arc/Info based Geographic Information System (GIS) with ERDAS IMAGINE 1 image processing software have been used in the present investigation. Both the data sets were geo- referenced, rectified and then merged. On-screen interpretation was performed on the merged satellite image. Based on the image characteristics which include location, tone and color, size, shape, texture, pattern, and association, landform / physiography of the area and land use, six image interpretation units were delineated. Image characteristics of the delineated units are given in table 1.

Table 1. Image characteristics of pre-field interpretation units

\begin{tabular}{|c|c|c|c|}
\hline $\begin{array}{c}\text { Image } \\
\text { interpretation unit } \\
\text { no. }\end{array}$ & Landform / slope & Landuse & Image characteristics \\
\hline 1 & Alluvial plain, highly sodic, levelled & Barren & $\begin{array}{l}\text { White with irregular pattern, no } \\
\text { field boundary }\end{array}$ \\
\hline 2 & Alluvial plain, slightly sodic, levelled & $\begin{array}{l}\text { Cultivated (poor } \\
\text { crop stand) }\end{array}$ & $\begin{array}{l}\text { White mixed with reddish } \\
\text { patches, regular field plots }\end{array}$ \\
\hline 3 & $\begin{array}{l}\text { Alluvial plain, low-lying, } \\
\text { submergence-prone }\end{array}$ & Cultivated & $\begin{array}{l}\text { Bluish black mixed with red and } \\
\text { brown patches, regular plot size }\end{array}$ \\
\hline 4 & Alluvial plain, levelled & $\begin{array}{l}\text { Cultivated (good } \\
\text { crop stand) }\end{array}$ & Reddish colour, regular plot size \\
\hline 5 & Alluvial plain, eroded, gently sloping & Cultivated & $\begin{array}{l}\text { Reddish colour, irregular field } \\
\text { plots, rough texture }\end{array}$ \\
\hline 6 & Alluvial plain, nearly leveled & Orchard & $\begin{array}{l}\text { Brown colour mixed with white } \\
\text { irregular field plots }\end{array}$ \\
\hline
\end{tabular}

Soil survey was carried out in the study area using the image interpretation unit map and a correlation between image characteristics, lanform and soil characteristics established in the field. Soil profiles were studied in each landorm unit, following the Soil Survey Manual (AISLUS, 1970). Auger bores were also taken in the same unit to verify the boundaries. A total of 22 soil profiles and 35 auger bores were studied. Horizon-wise samples were collected from representative pedons for laboratory analysis. Standard methods were followed for determining mechanical composition, $\mathrm{pH}$, EC, organic carbon, cation exchange capacity, base saturation and exchangeable sodium percentage (Jackson, 1973). Preliminary interpreted soil boundaries were modified in the light of field and laboratory information and the final soil map with legend was prepared. The soil map units is an association of soil series. The soils were also classified up to family level as per USDA soil Taxonomy (Soil Survey Staff, 2013).A flowchart showing the detailed methodology has been given as Fig. 2 . 


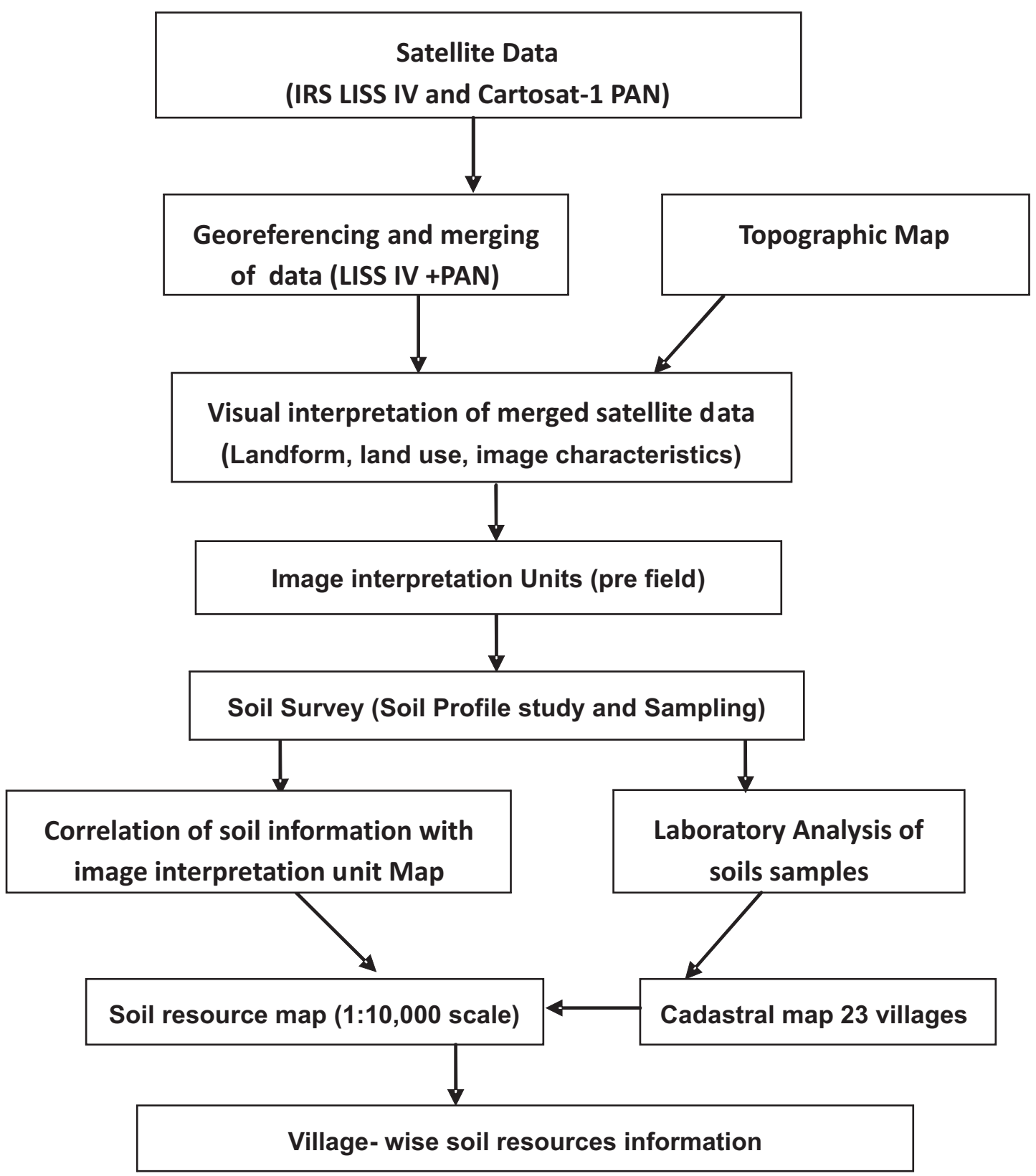

Fig 2. Methodology Flow Chart for Village- Level Soil Resources Information Generation.

Results and Discussion

Soilmap

Information on important site and morphological characteristics of soils were studied in the field has been presented in table 2. Physico-chemical characteristics of soils of representative pedons have been presented in table 3 . The soil map of the study area has been presented in fig. 3 and the detailed soil map legend given in table 4 . 


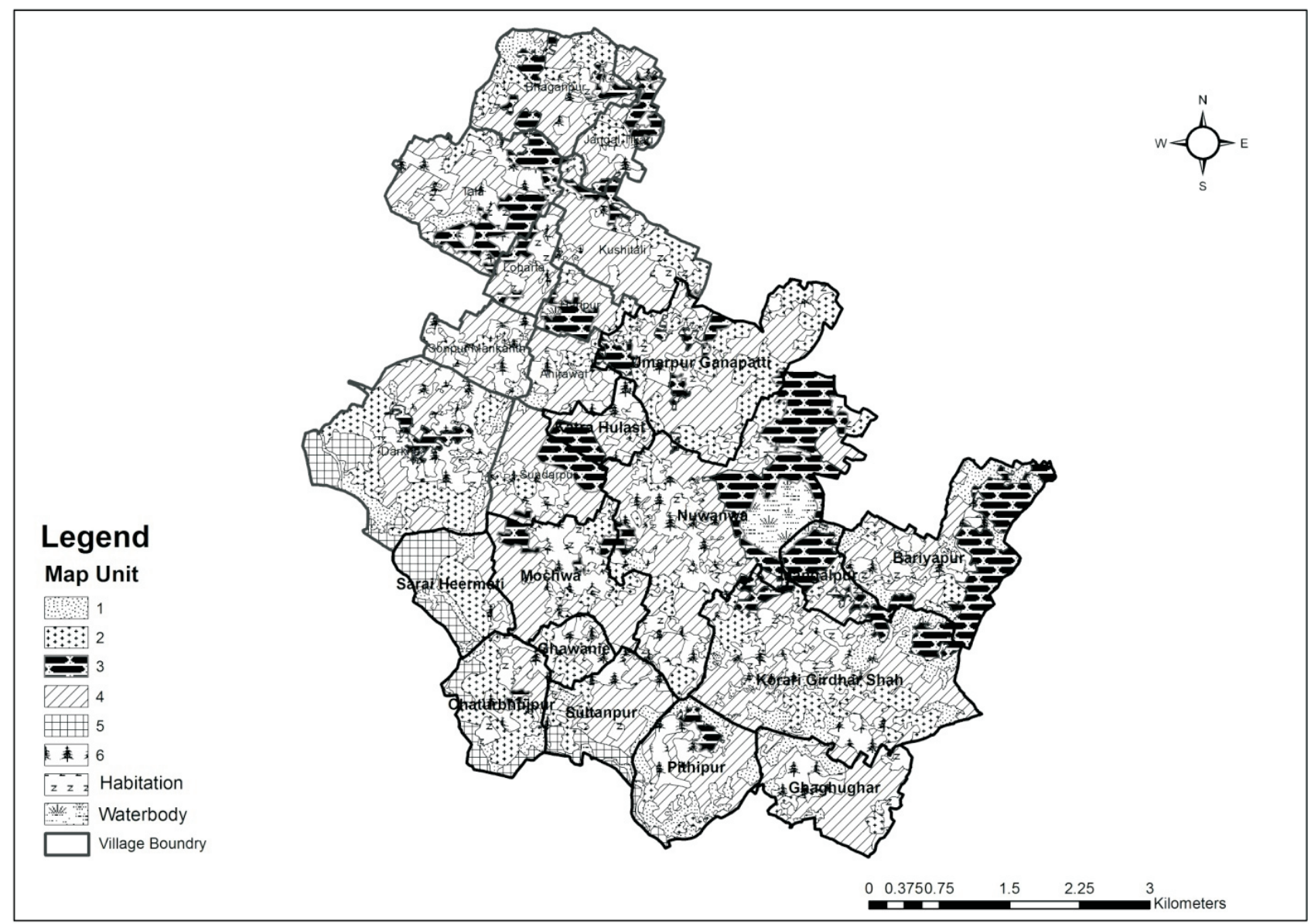

Fig. 3 Soil Map of Tala and Korari Girdhar Shah Nayapanchayat, distric Amethi, U.P.

Twelve tentative soil series have been established in the area. As can be seen on the soil map, each mapping unit is an association of two series. The soils of the mapping unit-1 (Bhaganpur- Bariyarpur series association) are highly sodic and are presently lying barren. The $\mathrm{pH}$ of the surface soil is more than 10 and ESP is more than 15 in all the horizons. These soils cover $8.1 \%$ of the area. The soils of the mapping unit-2 (Korari Girdhar Shah -Bhaganpur-II Series association) are cultivated but have low productivity due to marginal sodicity ( $\mathrm{pH}$ 8.4). The soils of the mapping unit-3
(Tala -Mangalpur Series association) have problem of water logging due to low- lying situation. Mapping unit-4 (Jhawanie- Lohrata series association) have good fertile soils. The $\mathrm{pH}$ is near natural in the surface and base saturation is high. These soils cover the largest area (36.3\% of the area). Mapping unit-5 (Sultanpur-Sarai Hirmati series association) have erosion problem due to their proximity to a local drain. Soils in the mapping unit-6 (KatraHulashi -Nunawan series association) are under orchards but the management practices need to be improved as most of the orchards are old. These soils cover $15.3 \%$ area. 


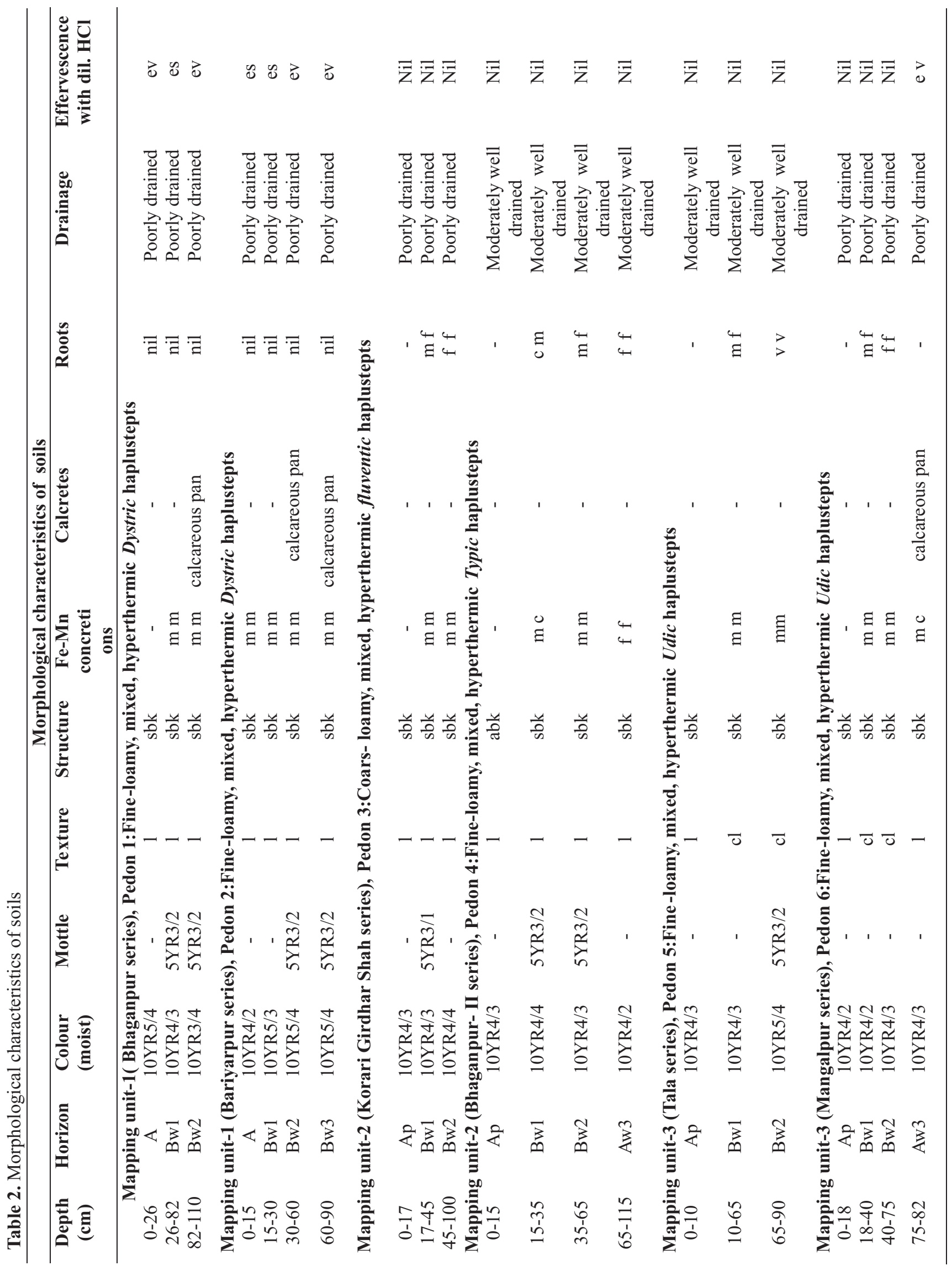




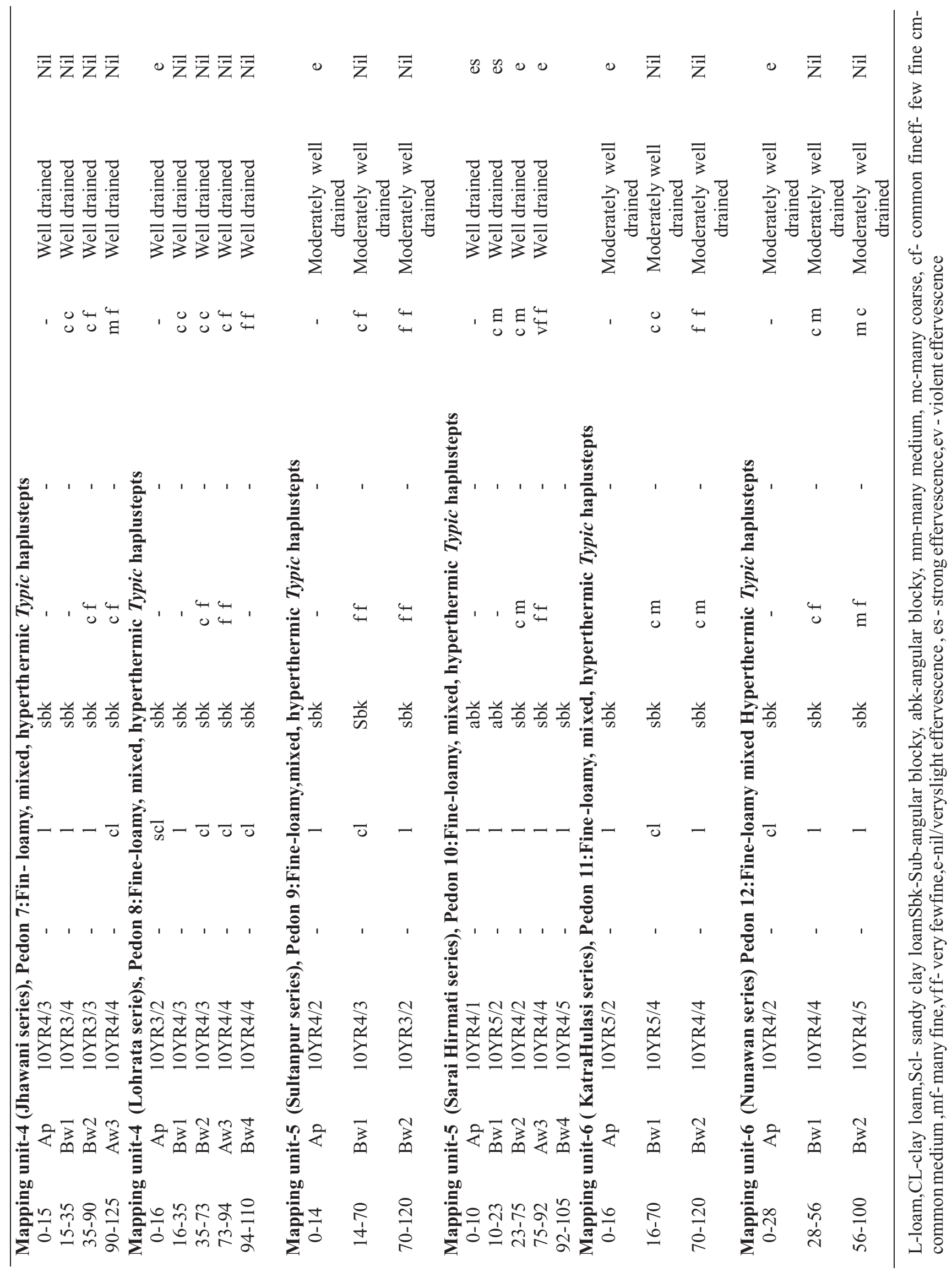


Table 3. Mechanical composition and Chemical characteristics of soils

\begin{tabular}{|c|c|c|c|c|c|c|c|c|c|c|}
\hline \multirow[t]{2}{*}{$\operatorname{Depth}(\mathrm{cm})$} & Sand & \multirow{2}{*}{$\begin{array}{l}\text { Silt } \\
\%\end{array}$} & \multirow{2}{*}{$\begin{array}{l}\text { Clay } \\
\%\end{array}$} & \multirow[t]{2}{*}{ Texture } & \multirow[t]{2}{*}{$\mathrm{pH}$} & \multirow{2}{*}{$\frac{\mathrm{EC}}{\left(\mathrm{dS}^{-1} \mathrm{~m}\right)}$} & \multirow{2}{*}{$\begin{array}{l}\text { O.C. } \\
(\%)\end{array}$} & \multirow{2}{*}{$\frac{\mathrm{CEC}}{\mathrm{cmol}\left(\mathrm{p}^{+}\right) \mathrm{kg}^{-1}}$} & \multirow{2}{*}{$\begin{array}{l}\text { BS } \\
(\%)\end{array}$} & \multirow{2}{*}{$\begin{array}{l}\text { ESP } \\
(\%)\end{array}$} \\
\hline & $\%$ & & & & & & & & & \\
\hline \multicolumn{11}{|c|}{ Pedon1:Fine-loamy Mixed Hyperthermic Dystric Ustochrepts } \\
\hline $0-26$ & 36.9 & 46.0 & 17.1 & & 10.4 & 3.5 & 0.03 & 13.42 & 68.24 & 17.14 \\
\hline $26-82$ & 32.9 & 40.0 & 27.1 & & 9.8 & 2.1 & 0.03 & 20.28 & 55.50 & 15.63 \\
\hline $82-110$ & 36.9 & 44.0 & 19.1 & & 8.7 & 1.7 & 0.10 & 14.61 & 50.40 & 15.42 \\
\hline \multicolumn{11}{|c|}{ Pedon 2:Fine-loamy Mixed Hyperthermic Dystric Ustochrepts } \\
\hline $0-15$ & 33.4 & 49.1 & 18.6 & & 10.2 & 4.1 & 0.05 & 16.58 & 53.14 & 16.24 \\
\hline $15-30$ & 36.9 & 44.0 & 18.3 & & 9.9 & 4.2 & 0.06 & 13.86 & 44.69 & 18.24 \\
\hline $30-60$ & 38.9 & 34.8 & 26.3 & & 10.1 & 3.6 & 0.04 & 15.32 & 55.61 & 17.75 \\
\hline $60-90$ & 42.9 & 33.8 & 22.3 & & 10.3 & 4.2 & 0.03 & 16.71 & 59.14 & 16.54 \\
\hline \multicolumn{11}{|c|}{ Pedon 3:Coarse-loamy, mixed, hyperthermic Fluventic Ustochrepts } \\
\hline $0-17$ & 38.9 & 42.0 & 19.1 & & 8.4 & 0.9 & 0.45 & 16.01 & 61.21 & 6.38 \\
\hline $17-45$ & 36.9 & 48.0 & 15.1 & & 8.2 & 0.9 & 0.51 & 13.28 & 79.63 & 6.96 \\
\hline $45-100$ & 39.3 & 42.0 & 17.9 & & 7.9 & 0.8 & 0.55 & 15.52 & 73.30 & 4.91 \\
\hline \multicolumn{11}{|c|}{ Pedon 4:Fine-loamy, mixed, hyperthermic Typic Ustochrepts } \\
\hline $0-15$ & 38.9 & 28.0 & 19.1 & & 8.4 & 0.8 & 1.0 & 18.09 & 57.20 & 2.98 \\
\hline $15-35$ & 40.9 & 42.0 & 19.1 & & 8.1 & 0.9 & 1.0 & 18.17 & 43.54 & 1.96 \\
\hline $35-65$ & 36.9 & 40.0 & 25.1 & & 7.9 & 0.8 & 0.97 & 22.52 & 54.20 & 4.90 \\
\hline $65-115$ & 35.8 & 39.7 & 26.5 & & 8.4 & 0.8 & 0.97 & 18.09 & 57.20 & 2.98 \\
\hline \multicolumn{11}{|c|}{ Pedon 5:Fine-loamy, mixed, hyperthermic Udic Ustochrepts } \\
\hline $0-10$ & 38.9 & 38.0 & 23.1 & & 7.2 & 0.7 & 0.72 & 20.07 & 48.31 & 2.36 \\
\hline $10-65$ & 36.9 & 32.0 & 31.1 & & 7.4 & 0.8 & 0.74 & 26.10 & 26.80 & 3.40 \\
\hline $65-90$ & 34.9 & 36.0 & 29.1 & & 7.1 & 0.8 & 0.73 & 24.57 & 31.47 & 1.81 \\
\hline \multicolumn{11}{|c|}{ Pedon 6:Fine-loamy, mixed, hyperthermic Udic Ustochrepts } \\
\hline $0-18$ & 30.3 & 29.6 & 21.1 & & 7.6 & 0.9 & 0.82 & 18.98 & 62.63 & 4.74 \\
\hline $18-40$ & 39.3 & 39.6 & 29.1 & & 7.5 & 0.8 & 0.86 & 25.09 & 65.24 & 3.16 \\
\hline $40-75$ & 41.3 & 31.6 & 27.1 & & 6.9 & 0.8 & 0.85 & 23.56 & 50.64 & 2.31 \\
\hline $75-82$ & 39.3 & 31.6 & 25.1 & & 7.1 & 0.7 & 0.78 & 21.80 & 66.22 & 3.44 \\
\hline \multicolumn{11}{|c|}{ Pedon 7:Fine-loamy, mixed, hyperthermic Typic Ustochrepts } \\
\hline $0-15$ & 42.1 & 34.4 & 23.5 & & 7.1 & 0.8 & 0.40 & 19.09 & 61.32 & 1.56 \\
\hline $15-35$ & 42.1 & 34.4 & 23.5 & & 7.3 & 0.8 & 0.71 & 20.33 & 60.35 & 1.40 \\
\hline $35-90$ & 38.1 & 40.4 & 21.5 & & 7.1 & 0.8 & 0.66 & 18.64 & 60.55 & 1.67 \\
\hline $90-125$ & 38.1 & 30.4 & 31.5 & & 6.9 & 0.9 & 0.69 & 26.20 & 46.35 & 1.40 \\
\hline \multicolumn{11}{|c|}{ Pedon 8:Fine-loamy, mixed, hyperthermic Typic Ustochrepts } \\
\hline $0-16$ & 56.5 & 22.4 & 21.1 & & 7.8 & 0.9 & 0.37 & 17.18 & 77.01 & 5.17 \\
\hline $16-35$ & 40.5 & 34.4 & 25.1 & & 7.6 & 0.9 & 0.40 & 20.28 & 77.00 & 2.69 \\
\hline $35-73$ & 38.5 & 34.4 & 27.1 & & 7.4 & 0.9 & 0.42 & 21.84 & 71.38 & 2.75 \\
\hline 73-94 & 36.1 & 30.4 & 33.9 & & 7.3 & 1.0 & 0.39 & 26.78 & 51.43 & 2.28 \\
\hline 94-110 & 38.1 & 30.0 & 31.9 & & 7.8 & 0.9 & 0.37 & 17.18 & 77.01 & 5.17 \\
\hline
\end{tabular}




\begin{tabular}{|c|c|c|c|c|c|c|c|c|c|}
\hline \multicolumn{10}{|c|}{ Pedon 9:Fine-loamy, mixed, hyperthermic Typic Ustochrepts } \\
\hline $0-14$ & 42.9 & 40.0 & 17.1 & 7.8 & 0.8 & 0.49 & 14.68 & 78.25 & 5.67 \\
\hline $14-70$ & 40.9 & 32.0 & 27.1 & 7.2 & 1.6 & 0.43 & 21.88 & 69.50 & 2.89 \\
\hline $70-120$ & 38.9 & 48.0 & 13.1 & 7.0 & 1.5 & 0.37 & 11.23 & 67.52 & 4.81 \\
\hline \multicolumn{10}{|c|}{ Pedon 10:Fine-loamy, mixed, hyper thermic Typic Ustochrepts } \\
\hline $0-10$ & 38.5 & 44.4 & 17.1 & 7.9 & 0.9 & 0.49 & 14.68 & 73.24 & 7.52 \\
\hline $10-23$ & 40.5 & 44.4 & 15.1 & 8.3 & 0.8 & 0.50 & 13.24 & 68.50 & 8.08 \\
\hline $23-75$ & 38.5 & 36.4 & 25.1 & 8.7 & 1.1 & 0.51 & 20.72 & 51.35 & 5.46 \\
\hline $75-92$ & 36.5 & 38.4 & 25.1 & 7.2 & 0.7 & 0.48 & 20.60 & 52.51 & 4.94 \\
\hline $92-105$ & 36.5 & 42.4 & 25.1 & 7.9 & 0.8 & 0.45 & 20.48 & 60.24 & 4.84 \\
\hline \multicolumn{10}{|c|}{ Pedon 1:-Fin- loamy, mixed, hyperthermic Typic Ustochrepts } \\
\hline $0-16$ & 36.9 & 40.0 & 23.1 & 7.6 & 0.8 & 0.85 & 20.59 & 73.34 & 8.08 \\
\hline $16-70$ & 36.9 & 34.0 & 29.1 & 7.2 & 1.6 & 0.87 & 25.13 & 61.88 & 6.36 \\
\hline $70-120$ & 38.9 & 40.0 & 21.1 & 7.0 & 1.5 & 0.82 & 18.98 & 69.30 & 5.50 \\
\hline \multicolumn{10}{|c|}{ Pedon 12:Fine-loamy, mixed, hyperthermic Typic Ustochrepts } \\
\hline $0-28$ & 42.9 & 27.6 & 29.5 & 7.0 & 0.9 & 0.45 & 23.75 & 66.75 & 2.39 \\
\hline $28-56$ & 38.9 & 38.0 & 23.1 & 6.9 & 0.9 & 0.44 & 18.95 & 64.94 & 2.05 \\
\hline $56-100$ & 36.9 & 42.0 & 21.1 & 7.4 & 0.8 & 0.42 & 17.38 & 65.03 & 2.51 \\
\hline
\end{tabular}


P.P.S. Yadav et al.

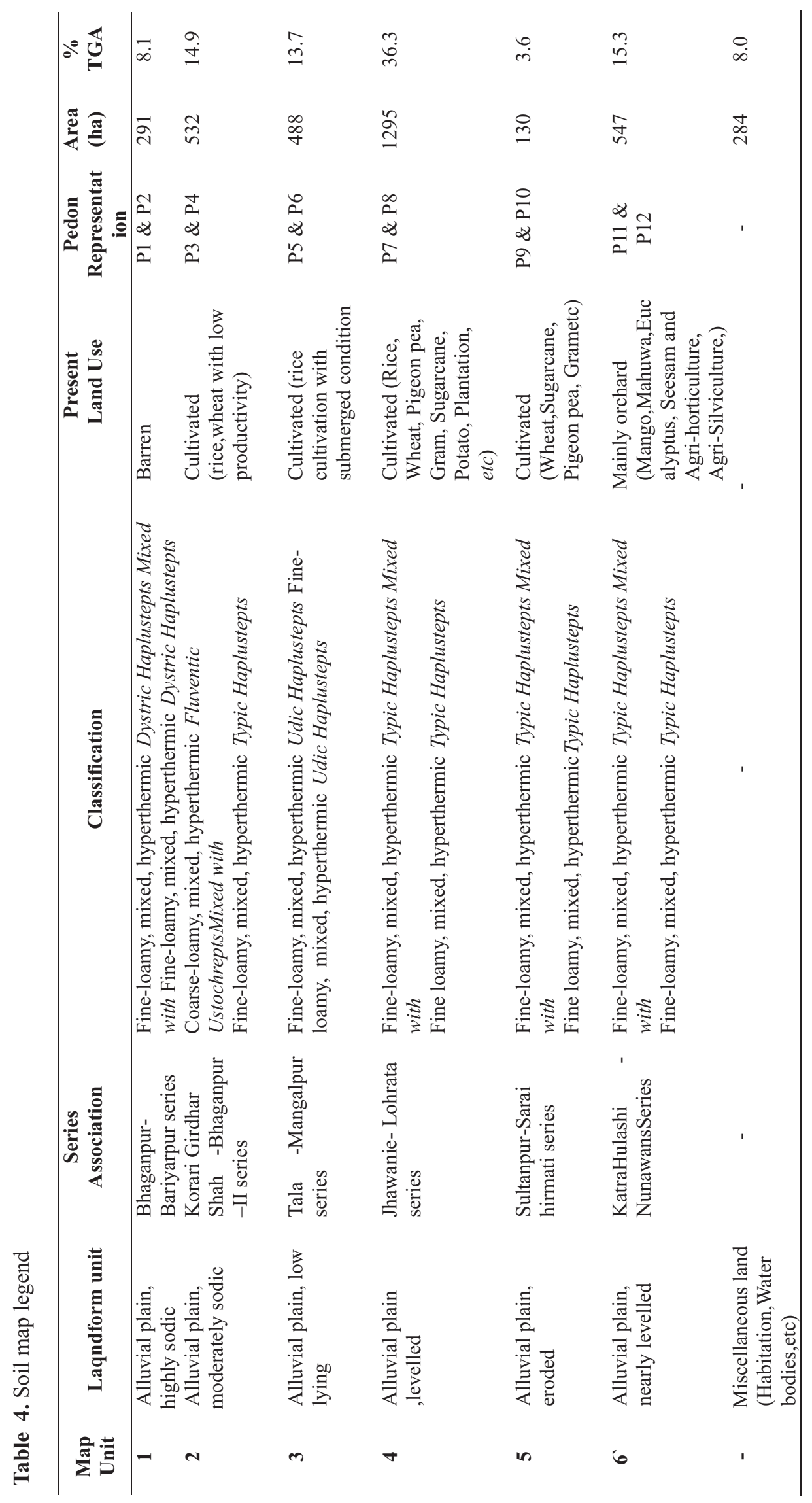




\section{Plot level information on Cadastral map}

The field/ farmer level utilization of soil map can be achieved only if the soil information is available with field numbers (khasra numbers) on the village map. To achieve this, the information on roads, habitation, field/ 'khasra' boundaries, canal, rail lines etc. was taken from the village cadastre, digitized, and overlaid on the soil map unit along with habitation boundaries for all the villages. A sample map of village Bhaganpur prepared with 'khasra' numbers and soil information is presented in fig-4. From the ownership of 'khasra' numbers in the village register, farmer level information can also be generated. The database on soils of each plot (khasra) and each farmer will be useful in resource potential assessment of every plot of the village.

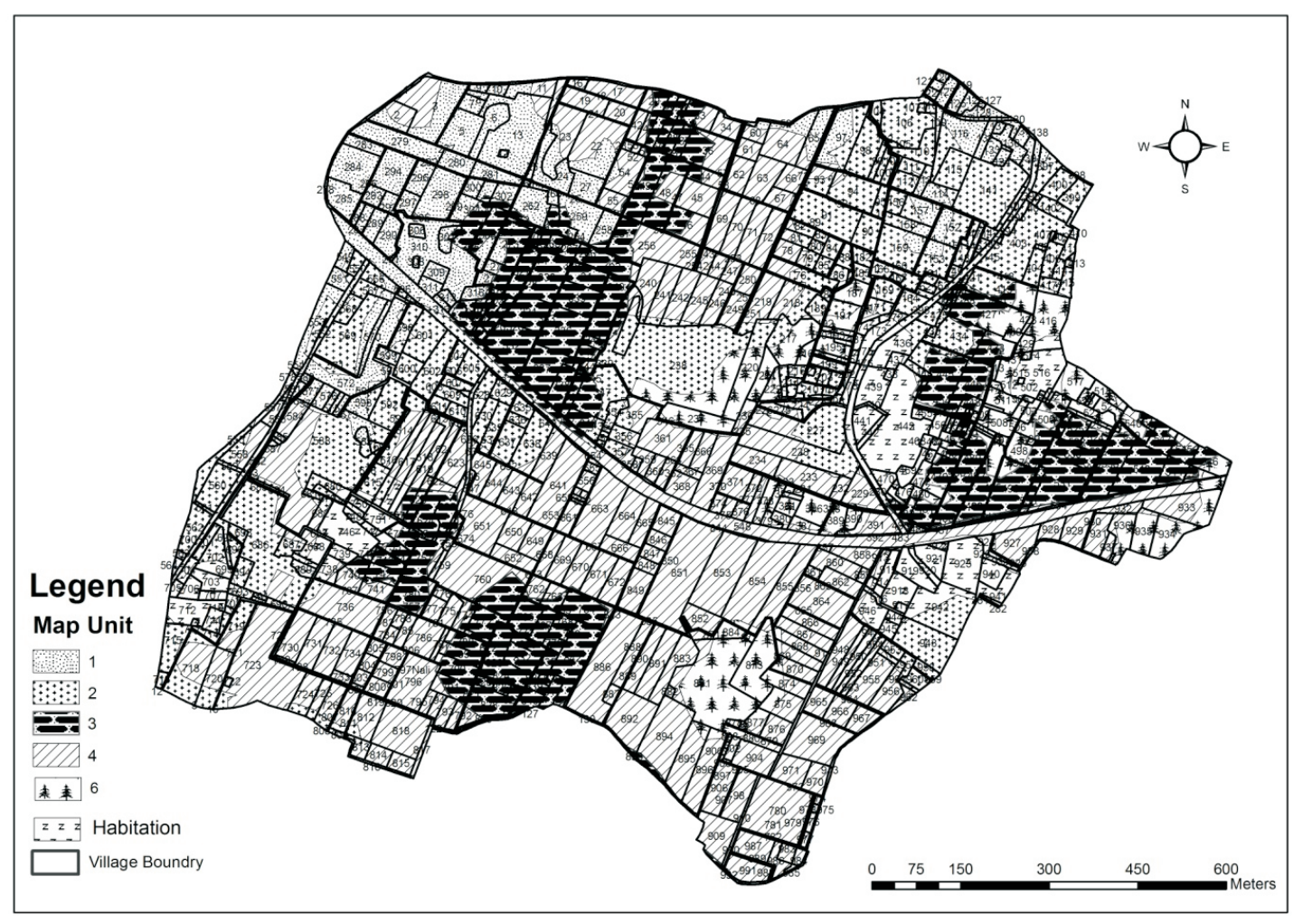

Fig. 4 Bhaganpur village Map of Tala Nayapanchayat, distric Amethi, U.P

\section{Land Use}

The land use analysis of the area showed that agriculture covers $68.78 \%$ of the total area of the two nyayapanchayats, followed by orchards $15.34 \%$, water body, river, canal and drain 1.64\%,wastelands (scrubland,sodic land,water logging) $8.34 \%$ and others (habitation etc.) $5.90 \%$.

\section{Interpretative grouping of soils of the area}

In order to assess the soils of the area for capability, suitability for irrigation and for growing different crops, each soil unit was placed into different classes of interpretative grouping. The Framework for Land Evaluation (FAO,1976) was followed for determining the crop suitability. The placement of each soil unit into land capability classification, land irrigability, Storie index rating, and crop suitability is presented in table 5 .

The Land capability class (Table 5) shows that the Bhaganpur-Bariyarpur soils (Map unit -1) have been placed in Class-IVs due to limitations of severe sodicity. Korari Girdhar Shah-Bhaganpur -II (Map unit-2 ) have been grouped in class IIIs due to limitation of moderate sodicity. Tala-Mangalpur soils (Map unit-3) have limitation of poor drainage and hence placed in the class IIw, whereas Sultanpur- Sarai Hirmati soils (Map unit-5) have limitation 
of erosion (gentle slope) and placed in class IIe. KatraHulashi-Nunawan soils (Map unit-6) have been grouped in class II with slight limitation poor drainage. The Jhawanie-Lohrata soils (Map unit-4) have no limitation and hence placedunder class I

The land irrigability classes were determined based on soil and site characteristics. Soil unit 1 has been placed in class 3 because of higher amount of $\mathrm{CaCO}_{3}$ and poor sub-soil drainage, where as soil units 2, 3, and 5 have moderate limitation, and therefore placed under class 2 . Soil unit 4 has no soil limitation for sustained use under irrigation and hence placed in class 1 .

Storie Index rating shows that the soil unit- 4 covers $36.3 \%$ area and qualifies for excellent rating, whereas unit 2 , covering $14.9 \%$ area qualifies for poor quality land. Unit 3 has been placed in fair good quality land due to wetness problem and covers $13.7 \%$ area. Unit 5 has slight to moderate erosion problem and placed under good quality land. Unit 1 which covers $8.1 \%$ area has been rated as very poor land because of its drainage and severe soil sodicity problem. Unit 6 which covers $15.3 \%$ land has been rated as good quality.

The soil suitability for major crops, like- wheat, been assessed based on FAO Framework for Land Evaluation (1976). The suitability classes are marked as highly suitable (S1), moderately suitable (S2), marginally suitable (S3) and temporarily unsuitable (N1) for a particular crop. The suffix $n$ represents salinity limitation, $s$ represents physical limitation influencing soil/ water relationship and management, $f$ represents soil fertility limitation, $t$ represents topographic limitation, and $w$ represents limitation of wetness.

\section{Action plan for soil water conservation measures}

An action plan for soil and water conservation has also been prepared to help in the watershed development programme in the area. The action plan map has been presented as Fig 5 and Table 6 presents the details of the activities to be taken up in the area. The soils of map unit -1 require reclamation of sodicity by adding of gypsum and then adoption of rice-wheat- dhaincha cropping system. Map unit-2 requires contour bunding and agronomic practices to conserve soil and water, whereas mapping unit-3 soils require drainage improvement. Map unit-5 needs contour bunding and other vegetative measures for soil erosion control.

rice, sugarcane, pigeon pea, gram,potato and plantation has

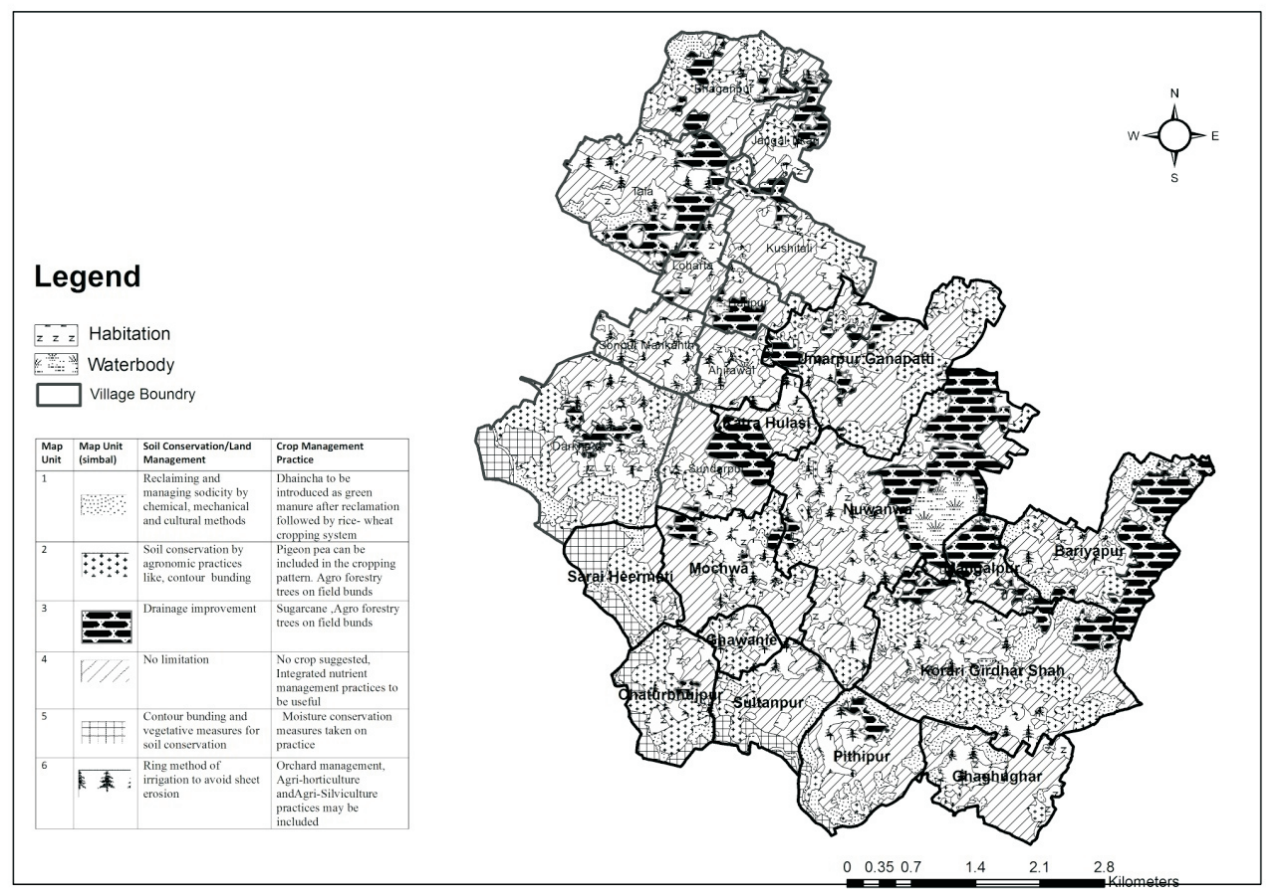

Fig. 5 Suggested conservation measures and crop management practices in Tala and Korari Girdhar Shah Nayapanchayat, distric Amethi, U.P 

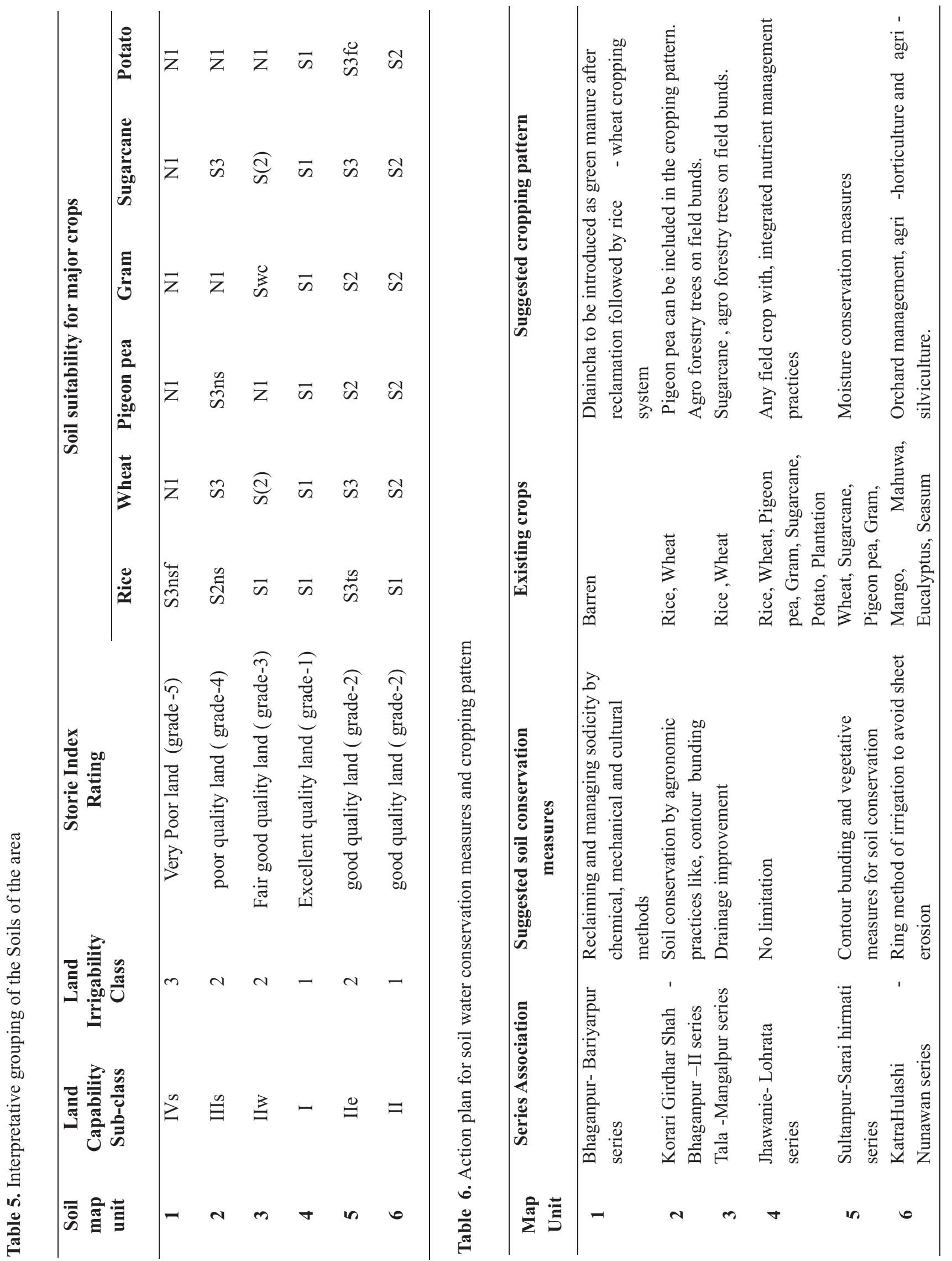


\section{Conclusion}

This study has shown that IRS LISSIV and Cartosat-1 PAN data is helpful in generating village level soil resource information on 1:10,000 scale. The landformsoil relationship can be studied on the high resolution satellite image. The soil mapping units consist of association of soil series, and soil phases in some cases. By integrating plot (khasra) information through GIS, farmer-wise and plot- wise soil information can be generated. These information will be helpful in planning soil and water conservation measures, land reclamation and crop management at the farm and at the village level. Various interpretative groupings viz. land capability, land irrigability, Storie index rating and suitability for important crops of for each soil unit will help in preparing land use plan of the village.

\section{Acknowledgements}

The authors are grateful to the Director, RSAC-UP, and Project Manager, DST funded Natural Resource Data Management System project at RSAC-UP, Lucknow. The present paper is a part of the study carried out by the authors in the DST, Govt. of India, supported Natural Recourse Data Management System project. Authors also acknowledge the support from Dr. A.N. Singh, former Director, RSAC-UP, in finalization of manuscript.

\section{References}

AIS\&LUS (1970).'Soil Survey Manual'.(All India Soil \& Land Use Survey, IARI, New Delhi).

Anil Kumar K.S., Hegde R. and Ramesh Kumar S.C. (2010).Characterization of soils of a microwatershed in eastern dry zone of Karnataka. Agropedology 20, 182-188.

Ardak S.A., Nagaraju S.S., Prasad J., Srivastava R. and Barthwal A.K. (2010). Characterization and evaluation of land resources in Khapri village of Nagpur district, Maharashtra using high resolution satellite data and GIS. Agropedology 20 7-18.
Dwivedi R.S. (2001). Soil resource mapping: a remote sensing perspective.Remote Sensing Reviews 20, 89-122.

Dwivedi RS., Ramana K.V., Thammappa S.S. and Singh A.N. (2001). The utility of IRS 1C LISS-III and PAN merged data for mapping salt-affected soils. Photogrammetric Engineering\& Remote Sensing, 67, 1167-1175.

FAO (1976). Framework for land evaluation. FAO soils bulletin no.32. Food and Agricultural Organization, Rome.

Jackson M.L. (1973). 'Soil Chemical Analysis', (Prentice Hall of India Private Inc., New Delhi).

Jagdish Prasad, Ray S.K., Gajbhiye K.S. and Singh S.R. (2009). Soils of Selsura research farm in Wardha district, Maharashtra and their suitability for crops. Agropedology 19,84-91.

Kunwar P., Kachhwaha T.S., Kumar A., Agrawal A.K., Singh A.N. and Mendiratta N. (2010). Use of high resolution IKONOS data and GIS technique for transformation of land use/ land cover for sustainable development. Current Science 98, 204-212.

Kudrat M., Tiwari, A.K. and Manchanda M.L. (2000). Multilevel soil mapping using remote sensing.Technical report. ISRO-NNRMS-TR-1012000.Indian Space Research Organization, Bangalore.

Liengsakul M., Mekpaiboonwatana S., Pramojanee P., Bronsveld K. and Huizing H. (1993). Use of GIS and remote sensing for soil mappingand for locating new sites for permanent cropland-Acasestudyin the highlands of northern Thailand Geoderma 60, 293-307.

Rao B.R.M., Fyzee M.A. and Wadodkar M.R. (2004).Utility of remote sensing data for mapping soils at various scales and levels.In'Soils and Crops'. (Eds.L. Venkataratnam, T. Ravisankar and R. Sudarshana, National Remote Sensing Agency, Hyderabad).

Ravisankar T. and Thamappa S.S. (2004).Satellite data interpretation and analysis for soil mapping.In'Soils and Crops'. (Eds.L. Venkataratnam, T. Ravisankar, and R. Sudarshana. National Remote Sensing Agency, Hyderabad). 
Sah K.D., Sarkar D., Seal A. and Singh D.S. ( 2010). Microlevel planning for optimal land use in coastal area of West Bengal-A case study. Agropedology 20,19-29. Sahu Nisha, Obi Reddy G.P., Kumar N., Nagaraju M.S.S., Srivastava R. and Singh S.K. (2014). Characterization of landforms and landuse/land cover in basaltic terrain using IRS-P6 LISS-IV and Cartosat-1 DEM data: A case study. Agropedology 24,166-178.

Sahu Nisha, Singh S.K., Obi Reddy G.P., Kumar N., Nagaraju M.S.S. and Srivastava R. (2016). Large scale soil resource mapping using IRS P-6 LISS IV and Cartosat-1 DEM in basaltic terrain of Central India. Journal of the Indian Society of Remote Sensing, 44, 811-819.

Sankar M., Sivasamy R. and Dadhwal K.S.( 2010). Land resources data and its evaluation for village level land use planning. Agropedology 20,1-6.

Anonymous (1988). Report on detailed soil survey of block Amethi and district Sultanpur.ShardaSahayak Command Area Development Project, JawaharBhavan, Lucknow, Uttar Pradesh.
Simon P. (2010). 'Remote sensing in geomorphology', (OxfordBook Company, Jaipur).

Singh A.N. and Dwivedi R.S. (1986). The utility of Landsat imagery as an integral part of the database for small scale soil mapping. International Journal of Remote Sensing, 7, 1099-1108.

Srivastava R. and Saxena R.K. (2004).Technique of large scale soil mapping in basaltic terrain using satellite remote sensing data. International Journal of Remote Sensing 25, 679-688.

Soil Survey Staff (2013). 'Simplified Guide to Soil Taxonomy'.(USDA-Natural Resources Conservation Service, National Soil Survey Center, Lincoln, Nebraska).

Wadodkar M.R., and Ravisankar T. (2011). Soil resource database at village level for developmental planning. Journal of the Indian Society of Remote Sensing 39, 529-536.

Received: March 2016 Accepted: November 2016 